\title{
Variability of dairy wastewater characteristics in Piatnica - one of the largest and most advanced milk processing plants in Poland
}

\author{
Joanna Struk-Sokolowska ${ }^{1, *}$ \\ ${ }^{1}$ Bialystok University Of Technology, Faculty of Civil and Environmental Engineering, Department \\ of Environmental Engineering Technology and Systems, Wiejska St. 45E, Bialystok 15-351, Poland
}

\begin{abstract}
The problem of industrial wastewater treatment from food processing, including dairy, is not completely solved. The aim of this study was to determine the variability of dairy sewage characteristics in one of the largest and most advanced milk processing plants in Piatnica, EastNorth Poland and review the opportunities for biological removal of nitrogen and phosphorus from wastewater. The study was conducted in the milk processing plant and WWTP in 2016 and 2017. The ratio of organic compounds for biogenic compounds in dairy wastewater were determined. During the two year study period there were no instances when the ratio of organic compounds for total phosphorus in Piatnica raw wastewater was lower than $25 \mathrm{gBOD}_{5} \cdot \mathrm{gP}^{-1}$. This indicates that in modern and innovative milk processing plants there are no instances when the amount of organic matter in dairy sewage is insufficient to remove phosphorus below $1.0 \mathrm{mgP} \cdot \mathrm{dm}^{-3}$.
\end{abstract}

\section{Introduction}

Dairy industry is one of the biggest sources of industrial wastewater in Europe and the problem of dairy sewage treatment is not completely solved, especially in plants of medium and small milk processing capacity. Dairy wastewater is characterized by high load of COD and $\mathrm{BOD}_{5}$ [1-3]. This includes dissolved and crystallized fats (glycerol, triglycerides), sugars (lactose) and protein (casein) in colloidal form and as clots; shares of these substances can vary. Nitrogen in dairy sewage occurs in the form of organic nitrogen (proteins, urea, nucleic acids) and $\mathrm{NH}_{4}{ }^{+}, \mathrm{NO}_{2}{ }^{-}$and $\mathrm{NO}_{3}{ }^{-}$ions and its main source are milk proteins [4]. Some of them like casein, are resistant to biodegradation and thus require properly adapted microorganisms for biological degradation. Quantity of dairy sewage is characterized by high seasonal variations (20\% increase in spring and summer). Additional oscillations relate to the daily and hourly shift work dependent on the size, production profile, and shifts at milk processing plant [1-13]. Dairy wastewater is normally treated by physical, biological and chemical processes and the various possibilities are presented in fig. 1. Biological treatment of dairy wastewater with an activated-sludge process is high-efficient due to the significant share of easily biodegradable substances.

\footnotetext{
*Corresponding author: j.struk@pb.edu.pl
} 
Dairy sewage contains compounds necessary for the growth of microorganisms during aerobic treatment.

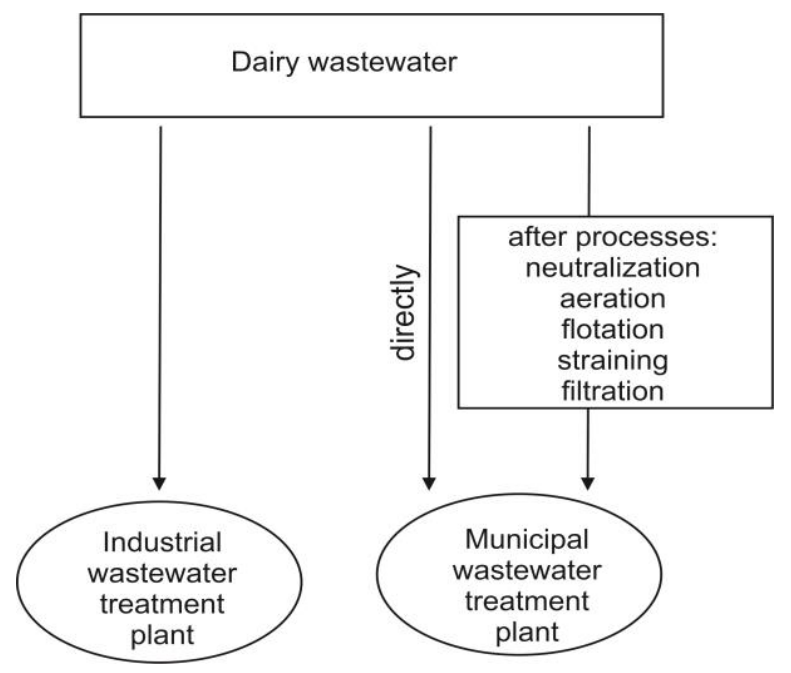

Fig. 1. The possibilities of dairy wastewater treatment and co-treatment.

Susceptibility to biological degradation of substances contained in dairy wastewater depends on the type of wastewater generated in a given milk processing plant [12-16]. For the oxygen decomposition of lactose the presence of other compounds that are a source of nitrogen and phosphorus is necessary. Proteins are broken down into amino acids and ammonia. Long-chain saturated fatty acids (12 - 14 carbon atoms) and unsaturated fatty acids (18 carbon atoms) have a negative effect on activated sludge microorganisms, in particular for methanogenic bacteria [17] because of the double bonds and cis isomers found in natural fats.

The by-product of dairy industry is whey which contains lactose, proteins, calcium and phosphorus compounds, organic acids and vitamins. Depending on the method of milk protein precipitation and production technology dairy plants produce two types of whey: rennet ( $\mathrm{pH}$ 5.2-6.7) in the production of ripening cheese and acidic whey ( $\mathrm{pH} 3.8-4.6)$ from curd cheese production. As a consequence of membrane separation techniques becoming increasingly popular valuable substances are recovered from whey. In Poland as in most other EU countries whey is dried and milk processing plants that do not have milk powder producing technology sell liquid whey to other plants. In such cases whey is not discharged to sewage but treated as a raw material for the production of foodstuffs, pharmaceuticals or feed components [18].

The aim of this study was to determine the variability of dairy sewage characteristics in one of the largest and most advanced milk processing plants in Piatnica, Eastern Poland and review the opportunities for biological removal of nitrogen and phosphorus from wastewater.

\section{Materials and methods}

\subsection{Area of study}

The study was conducted in 2016 and 2017 in the Piatnica milk processing plant (Dairy Cooperative), East-North Poland and in the industrial wastewater treatment plant belonging to the milk processing plant. 


\subsubsection{Piatnica milk processing plant}

Piatnica is located in the Podlasie Region, East-North Poland on the Narew River (right tributary of the Vistula River). The Regional Dairy Cooperative in Piatnica annually purchases 333 million litres of milk from 2196 suppliers whose farms are located in the area called "The Green Lungs of Poland" recognized to be the cleanest part of the country. When verifying the quality of purchased milk in terms of bacteria content beside the EU standard Piatnica introduced his own standards twice as stringent as the requirements of the European Union. For the production purposes the best sensitive tests are used to detect antibiotic residues and inhibitory substances in milk. Piatnica has been paying the highest prices to farmers for high quality milk for the last 16 years and supporting them with specialist knowhow.

The Dairy Cooperative in Piatnica is the largest producer of cottage cheese in the world. It was the first dairy plant in Poland to introduce curd cheese in slices as well as organic milk production. Drinking milk production (ecological) is based on a method of microfiltration and pasteurization at $74{ }^{\circ} \mathrm{C} / 20 \mathrm{sec}$. In recent years Piatnica has continued to expand and modernize with total investments in 2014 amounting to over EUR 13 million and including the launch of new cottage cheese production line as well as a fully automated and climate controlled high storage 5,000 pallet warehouse, the first of it's type in Polish dairy plants. A line for the production of innovative $0 \%$ fat and double protein Greek yoghurt was launched in 2015. Piatnica started production of Greek type yoghurts containing only natural yoghurt and slightly sweetened fruit and was the first Dairy Cooperative in the country to implement IMS - Integrated Management System, including: Quality management system ISO 9001, food safety system according to HACCP, ISO 14001 environmental management system. Since 2010 this innovative and modern plant also boasts an international IFS (International Food Standard) certificate confirming that it meets all quality and food safety standards.

In 2011 Piatnica built it's own heat and power facility based on high-efficiency cogeneration principle where the production of electricity is combined with heat production. This facility covers the plant's total demand for electricity and a significant part for thermal energy. The fuel used for combustion is natural gas. Due to high energy efficiency of devices and avoidance of transmission losses, a high level of primary energy utilization contained in the gas fuel is obtained (75\%). Also a system for the purification and reuse of process water has been implemented which allowed for a significant reduction of water consumption by as much as $240 \mathrm{~m}^{3} \cdot \mathrm{day}^{-1}$. The water consumption index is currently 2.7 litres per each litre of processed milk which is best practice among milk processing plants in Poland. The indicator of water consumption in the milk processing plant in 2007-2017 is shown in Fig. 2.

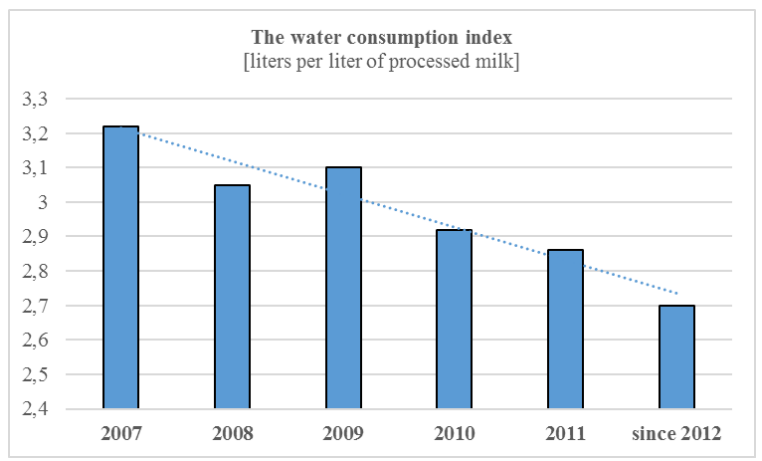

Fig. 2. The water consumption index in the milk processing plant in Piatnica in 2007-2017 [The Dairy Cooperative in Piatnica]. 
Production profile data of the dairy processing plant is provided in Table 1.

Table 1. Production characteristics of dairy processing plant in Piatnica.

\begin{tabular}{|c|c|}
\hline Amount of processed milk & Products \\
\hline $333,000,000 \mathrm{dm}^{3} \cdot \mathrm{year}^{-1}$ & cottage cheese (natural, with friut, vegetables, honey), \\
$912,329 \mathrm{dm}^{3} \cdot \mathrm{day}^{-1}$ & drining milk (2-3.2\% fat, free of lactose, organic), \\
& $\begin{array}{c}\text { cream (10-42\% fat), curd (natural, with vegetables, spices), } \\
\text { yogurt (natural, with fruit, Greek and Icelandic type), } \\
\text { mascarpone, butter, kefir (0-2\% fat), sour milk }\end{array}$ \\
\hline
\end{tabular}

Dairy sewage generated in production processes flows into the industrial wastewater treatment plant, the extension and modernization of which ended in 2012.

\subsubsection{Industrial Wastewater Treatment Plant in Piatnica}

The dairy co-operative in Piatnica has a mechanical-biological wastewater treatment plant based on activated sludge method. The industrial wastewater treatment plant operates in a three-stage system with increased nitrogen and phosphorus removal. Industrial wastewater is created during the implementation of milk processing technologies such as:

- CIP (Clean in Place) CA 4-stream station - washing of whey and raw milk lines, storage and buffer tanks of the whey collection and concentration department, raw milk receiving lines, whey process lines, whey exchangers, milk tanks, raw milk pasteurizers

- CIP CB 8-stream station - washing of cheese line; fermentation boilers, backwoods, plate exchangers, towers, water and cream tanks, whey and water separators, creamers, packing machines. Technological line of cream and fluffy cheese, fermentation tanks, buffer and storage tanks. Plate exchanger with centrifuge, homogenizer and transmission lines, coolers and packers

- CIP CC 5-stream station - washing process line of cream and other fermentation products, fermentation and storage tanks for cream, plate and tube coolers, transmission lines, packing machines. Technological line of milk cream apparatus, fermentation and storage tanks, transmission lines. Technological line of mascarpone, cream container, storage tanks. Compaction system, plate exchanger with evaporator, homogenizer and transmission lines, packing machine. The technological line of the cream store, storage tanks, plate and tube exchanger, transmission lines

- Washing of remaining devices

- Permeate discharge from the whey dense line

- Rinsing water from the rinsing and regeneration of filters at the technological water treatment station

- Water from rinsing and regeneration of plasticizers at the boiler water treatment station. Table 2 shows the average flows and loads of dairy sewage treated in industrial wastewater treatment plant.

Table 2. Quantities and load of dairy wastewater.

\begin{tabular}{|c|c|c|}
\hline Quantities and load of dairy wastewater & unit & \\
\hline $\mathrm{Qd}_{\max }(\mathrm{d}$-daily; max - maximum) & $\mathrm{m}^{3} \cdot \mathrm{day}^{-1}$ & 3300 \\
\hline $\mathrm{Qd}_{\mathrm{av}}(\mathrm{d}-$ daily; av - average) & $\mathrm{m}^{3} \cdot \mathrm{day}^{-1}$ & 3000 \\
\hline $\mathrm{Qh}_{\mathrm{av}}$ (h-hourly; av - average) & $\mathrm{m}^{3} \cdot \mathrm{hour}^{-1}$ & 221 \\
\hline $\mathrm{PE}$ (equivalent population) & - & 68000 \\
\hline Load of BOD5 (biochemical oxygen demand) & $\mathrm{kg}^{-}$day $^{-1}$ & 4097 \\
\hline
\end{tabular}

Table 3 presents facilities for dairy wastewater treatment plant in Piatnica. 
Table 3. Facilities for dairy wastewater treatment plant in Piatnica.

\begin{tabular}{|c|c|c|}
\hline No & Facility & Additional information \\
\hline \multicolumn{2}{|c|}{ MILK PROCESSING PLANT } & dairy sewage flows in a collector $(600 \mathrm{~m}$ ) by gravity \\
\hline 1. & grit chamber & slope of 60 degrees, ground clearance $10 \mathrm{~mm}$ \\
\hline 2. & horizontal sand separators & $2,12 \mathrm{~m}$ long, work alternately or in combination \\
\hline 3. & pumping station & - \\
\hline 4. & expansion tank & optionally used \\
\hline 4. & chamber of dephosphatation & usable volume $190 \mathrm{~m}^{3}$ \\
\hline 5. & chamber of denitrification & usable volume $504 \mathrm{~m}^{3}$ \\
\hline 5. & reserve chamber & usable volume $2218 \mathrm{~m}^{3}$, optionally used \\
\hline 6. & chamber of nitrification $5540 \mathrm{~m}^{3}$ \\
\hline 7. & secondary settling tank & radial, diameter $21 \mathrm{~m}$ \\
\hline \multicolumn{2}{|c|}{ THE NAREW RIVER (the sewage receiver) } & falls into the Vistula River - falls into the Baltic Sea \\
\hline
\end{tabular}

\subsection{Analytical Methods}

The scope of analytical determinations made in samples of dairy wastewater included analysis of the following indicators: $\mathrm{BOD}_{5}, \mathrm{COD}_{\mathrm{Cr}}, \mathrm{TSS}, \mathrm{NH}_{4}{ }^{+}-\mathrm{N}, \mathrm{N}_{\text {tot }}, \mathrm{P}_{\text {tot }}$, Ether extract in raw dairy wastewater. Analyses were carried out in accordance with APHA (2012) [19]. Based on the study results, ratio of organic compounds $\left(\mathrm{BOD}_{5}, \mathrm{COD}\right)$ for biogenic compounds $\left(\mathrm{N}_{\text {tot }}, \mathrm{P}_{\text {tot }}\right)$ were carried out. The ratio of organic compounds in raw dairy wastewater was determined from the formula:

$$
Q_{1}=C O D / B O D_{5}
$$

$C O D$ - the oxidizable organic matter in raw dairy wastewater, $\mathrm{g} \cdot \mathrm{m}^{-3}$

$B O D_{5}$ - the amount of biodegradable organic matter in raw dairy wastewater, $\mathrm{g} \cdot \mathrm{m}^{-3}$

To determine the ratio of organic compounds for biogenic compounds in raw dairy wastewater, following dependences were applied:

$$
Q_{2}=B O D_{5} / N_{\text {tot }}
$$

$N_{\text {tot }}$ - concentration of total nitrogen in raw dairy wastewater, $\mathrm{g} \cdot \mathrm{m}^{-3}$

$$
Q_{3}=B O D_{5} / P_{t o t}
$$

$P_{t o t}-$ concentration of total phosphorus in raw dairy wastewater, $\mathrm{g} \cdot \mathrm{m}^{-3}$

$$
\begin{aligned}
& Q_{4}=C O D / N_{t o t} \\
& Q_{5}=C O D / P_{t o t}
\end{aligned}
$$

\section{Results}

Table 4 summarizes the characteristics of dairy wastewater from the milk processing plant in Piatnica in 2016 and 2017. The factor affecting the efficiency of pollutant removal from wastewater is their composition. The amount of easily decomposed organic compounds found in the sewage in relation to the nitrogen and phosphorus compounds directly affects the efficiency of nitrate nitrogen and phosphorus removal [20]. Figure 3 presents characteristics of dairy wastewater from 2 milk processing plants with different production profile - in Gizycko [27] and in Piatnica. The amount and type of organic compounds in wastewater are important for the course of denitrification. Literature shows that biological nitrogen removal processes run efficiently when $\mathrm{BOD}_{5}: \mathrm{N}_{\text {tot }}$ is at least $4: 1$ [21, 
22]. Based on the results of the study (tab. 4) it was found that the average value of $\mathrm{BOD}_{5}: \mathrm{N}_{\text {tot }}$ in dairy wastewater varied in a narrow range from 6.2 to $21.1 \mathrm{gBZT}_{5} \cdot \mathrm{gN}^{-1}$. The lowest value was recorded in February, while the highest in August 2016 (fig. 3).

Table 4. Characteristic of dairy wastewater at IWTP in Piatnica (2016-2017)

\begin{tabular}{|c|c|c|c|c|c|c|c|c|}
\hline \multicolumn{2}{|l|}{$\begin{array}{c}\text { Parameter } \\
\text { unit }\end{array}$} & II & IV & VI & VIII & $\mathbf{X}$ & XII & $\begin{array}{l}\text { Annual } \\
\text { average }\end{array}$ \\
\hline BOD5 $_{5}$ & $*$ & 1300.0 & 1100.0 & 1550.0 & 1920.0 & 1500.0 & 1770.0 & 1523.0 \\
\hline $\mathrm{gO}_{2} \cdot \mathrm{m}^{-3}$ & ** & 1550.0 & 1280.0 & 1260.0 & 1600.0 & 1440.0 & - & 1426.0 \\
\hline COD $_{\mathrm{Cr}}$ & * & 2180.0 & 2780.0 & 3830.0 & 4020.0 & 4570.0 & 2930.0 & 3385.0 \\
\hline $\mathrm{gO}_{2} \cdot \mathrm{m}^{-3}$ & $* *$ & 2670.0 & 2880.0 & 2720.0 & 2830.0 & 2810.0 & - & 2782.0 \\
\hline TSS & * & 510.0 & 460.0 & 770.0 & 620.0 & 1200.0 & 680.0 & 707.0 \\
\hline $\mathrm{g} \cdot \mathrm{m}^{-3}$ & ** & 540.0 & 450.0 & 660.0 & 730.0 & 750.2 & - & 626.0 \\
\hline $\mathrm{N}-\mathrm{NH}_{4}$ & * & 9.8 & 14.5 & 12.6 & 15.4 & 10.6 & 10.3 & 12.2 \\
\hline $\mathrm{gN}_{\mathrm{NH} 4} \cdot \mathrm{m}^{-3}$ & ** & 8.0 & 7.0 & 10.0 & 9.0 & 10.0 & - & 8.8 \\
\hline $\mathbf{N}_{\text {tot }}$ & $*$ & 210.0 & 196.0 & 106.0 & 91.0 & 92.0 & 106.0 & 133.0 \\
\hline $\mathrm{gN} \cdot \mathrm{m}^{-3}$ & ** & 109.0 & 121.0 & 155.0 & 102.0 & 78.0 & - & 113.0 \\
\hline $\mathbf{P}_{\text {tot }}$ & $*$ & 25.0 & 28.0 & 21.0 & 17.0 & 21.0 & 18.0 & 22.0 \\
\hline $\mathrm{gP} \cdot \mathrm{m}^{-3}$ & ** & 14.0 & 14.0 & 26.0 & 14.0 & 16.0 & - & 16.8 \\
\hline Ether ex. & $*$ & 201.0 & 331.0 & 607.0 & 499.0 & 656.0 & 400.0 & 449.0 \\
\hline $\mathrm{g} \cdot \mathrm{m}^{-3}$ & ** & 245.0 & 402.0 & 477.0 & 362.0 & 346.0 & - & 366.4 \\
\hline COD/BOD5 & * & 1.7 & 2.5 & 2.5 & 2.1 & 3.0 & 1.7 & 2.2 \\
\hline $\mathrm{gCOD} \cdot \mathrm{gBOD}_{5}{ }^{-1}$ & $* *$ & 1.7 & 2.3 & 2.2 & 1.8 & 2.0 & - & 2.0 \\
\hline BOD $_{5} / \mathbf{N}_{\text {tot }}$ & $*$ & 6.2 & 5.6 & 14.6 & 21.1 & 16.3 & 16.7 & 11.5 \\
\hline $\mathrm{gBOD}_{5} \cdot \mathrm{gN}^{-1}$ & ** & 14.2 & 10.6 & 8.1 & 15.7 & 18.5 & - & 13.4 \\
\hline $\mathrm{BOD}_{5} / \mathrm{P}_{\text {tot }}$ & $*$ & 52.0 & 39.3 & 73.8 & 112.9 & 71.4 & 98.3 & 69.2 \\
\hline $\mathrm{gBOD}_{5} \cdot \mathrm{gP}^{-1}$ & ** & 110.7 & 91.4 & 48.5 & 114.3 & 90.0 & - & 91.0 \\
\hline $\mathrm{COD} / \mathrm{N}_{\text {tot }}$ & $*$ & 10.4 & 14.2 & 36.1 & 44.2 & 49.7 & 27.6 & 25.5 \\
\hline $\mathrm{gCOD} \cdot \mathrm{gN}^{-1}$ & $* *$ & 24.5 & 23.8 & 17.5 & 27.7 & 36.0 & - & 25.9 \\
\hline COD/Ptot & * & 87.2 & 99.3 & 182.4 & 191.4 & 217.6 & 162.8 & 153.9 \\
\hline $\mathrm{gCOD} \cdot \mathrm{gP}^{-1}$ & $* *$ & 190.7 & 205.7 & 104.6 & 202.1 & 175.6 & - & 175.7 \\
\hline
\end{tabular}

The measure of complete biological removal of nitrogen from sewage in the activated sludge chambers is also the ratio of added substrate (expressed in COD) to the concentration of total nitrogen [23]. According to literature when COD: $\mathrm{N}_{\text {tot }}<5$, the efficiency of nitrogen removal is very low, while COD: $\mathrm{N}_{\text {tot }}>9$ guarantees very high efficiency of nitrogen removal from wastewater [20, 24]. Based on the obtained results, it was found that the values of this ratio in dairy wastewater exceeded 9 (range 10.4-49.7), which means that the denitrification taking place in the activated sludge chamber will not be limited by the availability of organic substrate. Values of the ratio COD: $\mathrm{N}_{\text {tot }}$ in dairy sewage from Piatnica were similar to those given by Janczukowicz [20] and on average almost 3 times higher than the value considered to guarantee total denitrification in activated sludge.

In the wastewater treatment plant where biological phosphorus removal occurs, the ratio of COD: $\mathrm{P}_{\text {tot }}(40: 1)$ is much more reliable than $\mathrm{BOD}_{5}: \mathrm{P}_{\text {tot }}(20: 1)$ in predicting the concentration of total phosphorus in effluent below $1.0 \mathrm{mgP} \cdot \mathrm{dm}^{-3}[20,22,24]$. When the ratio COD: $\mathrm{P}_{\text {tot }}$ is below 36 , the removal efficiency of the total phosphorus decreases. Fudala-Ksiazek [25] states that when the ratio COD: $P_{\text {tot }}$ is over 50, a high degree of biological dephosphattion can be achieved (phosphorus concentration in the effluent below $2.0 \mathrm{mgP} \cdot \mathrm{dm}^{-3}$ ). The lower value of the ratio makes it impossible to achieve high biological effectiveness of phosphorus removal and an additional process of chemical phosphorus precipitation should be applied [26]. The organic carbon management is therefore a very important aspect of the optimization of biological wastewater treatment 
[23]. In the case of phosphorus removal, the amount of the necessary organic substrate depends on the technological system used. Janczukowicz [20] reports that there are no reports in literature on the need to supply organic substances in excess of $43 \mathrm{gCOD} \cdot \mathrm{gP}^{-1}$ and $25 \mathrm{gBOD}_{5} \cdot \mathrm{gP}^{-1}$, however, for the process of wastewater treatment in SBR reactors that guarantees phosphorus removal $<1.0 \mathrm{mgP} \cdot \mathrm{dm}^{-3}$, values above $25 \mathrm{gBOD}_{5} \cdot \mathrm{gP}^{-1}$ should be used. Based on the obtained test results, it was found that the value of the ratio COD: $\mathrm{P}_{\text {tot }}$ in dairy wastewater from Piatnica was from 87.2 to $217.6 \mathrm{gCOD} \cdot \mathrm{gP}^{-1}$ (fig. 3). The ratio $\mathrm{BOD}_{5}: \mathrm{P}_{\text {tot }}$ in dairy wastewater varied in a narrow range from 39.3 to $114.3 \mathrm{gBOD}_{5} \cdot \mathrm{gP}^{-1}$ and was in the range given by Janczukowicz [20].

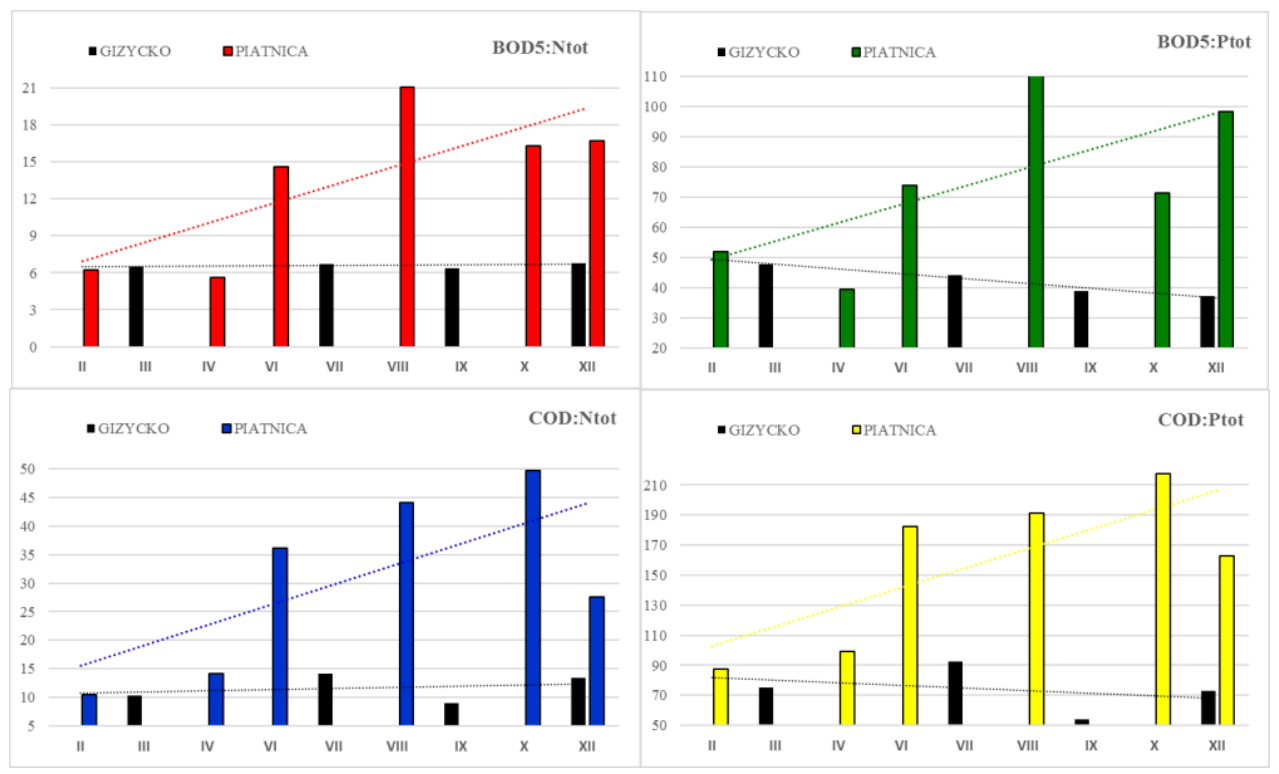

Fig. 3. A comparison of the ratio $\mathrm{BOD}_{5}: \mathrm{N}_{\text {tot }}, \mathrm{BOD}_{5}: \mathrm{P}_{\text {tot }}, \mathrm{COD}: \mathrm{N}_{\text {tot }}, \mathrm{COD}: \mathrm{P}_{\text {tot }}$ in dairy wastewater from milk processing plants in Gizycko (2015) [27] and Piatnica (2016) by months.

\section{Conclusions}

Based on the characteristics of dairy sewage from the Piatnica milk processing plant the following conclusions were drawn:

- In two-year studies there were no cases when the value of the ratio $\mathrm{BOD}_{5}: \mathrm{P}_{\text {tot }}$ in dairy wastewater was lower than $25 \mathrm{gBOD}_{5} \cdot \mathrm{gP}^{-1}$ (the recommended in literature) which indicates that in modern and innovative milk processing plant there are no occurrences when the amount of organic matter in dairy sewage is not sufficient to remove phosphorus below $1 \mathrm{mgP} \cdot \mathrm{dm}^{-3}$.

- The composition of dairy sewage from Piatnica guarantees more highly effective denitrification in activated sludge and biological dephosphatation than the composition of dairy sewage from other milk processing plants, eg in Gizycko (a different production profile including ripened cheese, butter, powder products and curd).

- In Piatnica it will be possible to obtain sewage parameters at a lower level than at present when the legal requirements for effluent will become more restrictive in the future.

Piatnica President Zbigniew Kalinowski and Environmental Specialist Krzysztof Staniszewski have been very helpful in providing data and detailed information for the creation of this article. 
Elzbieta Jakubczyk, PhD from the Dairy Technology Diploma Holders Association in Poland has kindly supported the author of this article with her extensive knowledge.

The research has been carried out in the framework of project No. S/WBiIS/3/2014 and financed from the funds for science by Ministry of Science and Higher Education.

\section{References}

1. D. Karadag, O.E. Köroğlu, B. Ozkaya, M. Cakmakci, Process Biochem. 50, no. 2, 262-271 (2015)

2. B. Demirel, O. Yenigun, T. T. Onay, Process Biochem., 40, no. 8, 2583-2595 (2005)

3. J. Struk-Sokolowska, J. Rodziewicz, ASEE17, E3S Web of Conf., 22, no. 00169 (2017)

4. L. Rodríguez, J. Villaseñor, F. J. Fernández, Wat. Scie. Tech., 55, no. 10, 63-70 (2007)

5. F. M. E. Emerald, D. T. S. A. Prasad, M. R. Ravindra, H. A. Pushpadass, Intern. Journ. Dairy Techn., 65, no. 4, $609-615$ (2012)

6. Y. W. Gong, H. X. Hang, X. N. Cheng, Wat. Scie. Tech., 65, no. 5, 915-919 (2012)

7. W. Janczukowicz, S. Grabowski, J. Pesta, R. Brzozowska, Pol. J. Natur. Sc., 22, no. 2, 256-270 (2007)

8. S. J. Lim S, P. Fox, Bios. Tech., 102, 10371-10376 (2011)

9. N. Mehrdadi, G. R. Nabi Bidhendi, M. Shokouhi, Wat. Scie. Tech., 65, no. 8, 14411447 (2012)

10. E. Neczaj, M. Kacprzak, T. Kamizela, J. Lach, E. Okoniewska, Desali., 222, 404-409 (2008)

11. M. Passeggi, I. Lopez, L. Borzacconi, Wat. Scie. Tech., 59, no. 3, 501-506 (2009)

12. T. Z. Pentado, R. S. S. Santana, A. L. B. Dibiazi, S. C. Pinho, R. Ribeiro, G. Tommaso, Wat. Scie. Tech., 63, no. 5 (2011)

13. J. Struk-Sokolowska, M. Puchlik, E3S Web Conf. 17, no. 00088, (2017)

14. A. Tawfik, M. Sobhey, M. Badawy, Desali. 227, 167-177 (2008)

15. A. A. L. Zinatizadeh, Y. Mansouri, A. Akhbari, S. Pashaei, Chem. Indust. Chem. Engine. Quart., 17, no. 4, 485-495 (2011)

16. R. Ayeche, Energy Proc., 18, 147-156 (2012)

17. W. Janczukowicz, M. Zieliński, M. Dębowski, Biores. Techn., 99, 4199-4205 (2008)

18. J. Struk-Sokolowska, PhD thesis, Bialystok University of Technology (2015)

19. E. W. Rice, R. B. Baird, A. D. Eaton, L. S. Clesceri, Standard Methods for the Examination of Water and Wastewater, Ame. Pub. Hea. Ass. (APHA), Ame. Wat. Wor. Ass. (AWWA), Wat. Envir. Fed. (WEF), 22 nd Edition (2012)

20. W. Janczukowicz, Postdoc. Dissert., Univ. of Warmia and Mazury, (2005)

21. E. Kalinowska, G. Bonar., J. Duma, LEMtech Kons., Cracow (2008)

22. M. Wojnicz, A. M. Anielak, Arch. Env. Prot., 36, no. 3, 27-37 (2010)

23. S. Myszograj, Gaz, Woda, Tech. San., VII-VIII (2009)

24. Z. Sadecka, Seidel-Przywecki, Warsaw (2010)

25. S. Fudala-Ksiazek, PhD thesis, Gdańsk University of Technology (2011)

26. K. Miksch, J. Sikora, PWN, Warsaw (2010)

27. J. Struk-Sokolowska, E. Wolejko, M. Puchlik, U. Wydro, Conf. Interdisc. Prob. Env. Prot. Eng. Eko-Dok, 7, 223-235 (2016) 